\title{
EDUCATIONAL POLICY IN BRITAIN
}

$\mathrm{T}$ HE debate on educational policy in the House of Lords on July 24, which was opened by the Earl of Longford, brought a spirited defence of Government policy from Lord Newton, but added substantially little to the present debate. The Earl of Longford had pointed out that the cost of education had risen from $£ 414$ million in 1951-52 to nearly $£ 1,250$ million in $1963-64$, and in the same period the percentage of the national income spent on education had increased from about $3 \cdot 1$ to $4 \cdot 9$. He agreed with Sir Edward Boyle's assumption that the reserve of potential ability among young people was not tapped to anything like the full extent. Lord Newton quoted also the view expressed by Sir Edward at Belfast on July 5 that if children were separated at any stage it should be done in their interests, and not because it pleased their parents or because of any social, class or colour distinction. We should work towards a situation in which every child had an equal chance of developing its interests and personality to the full. Defending the Government's impartiality regarding any particular pattern of secondary school organization, Lord Newton thought also that the achievements in school building had been considerable in terms alike of quantity and of economy and quality. This was due particularly to the work of the development group in the Ministry of Education, whose efforts now provided now schools at a cost, at constant prices, little more than half that in 1949 . Lord Newton also referred to the need to re-examine many traditional assumptions and practices about the organization of schools in Britain. Sir Edward Boyle at Belfast had suggested that there might be room for more flexibility in the size of the groups to be taught, that we should ask what were the limits of an acceptable balance between men and women in the different stages of the schools system, what were the true functions of a highly trained teacher and whether their skills and experience were at present being dissipated in tasks which might well be delegated to other hands. All these questions, Lord Newton observed, required discussion, and, while in the recruitment of part-time teachers much of the initiative must rest with the schools and the local education authorities, the Government could help, particularly by commissioning research into the obstacles to be over- come and into the most fruitful lines of development. To reduce all classes to 30 or less would require a further 110,000 teachers, while the decision taken in January to increase the capacity of the training colleges to 80,000 students by 1970 would only give a net addition of 5,000 teachers during the decade.

In a maiden speech, Viscount Samuel, directing attention to the possibility of technological unemployment as the result of automation in industry, stressed the urgency of raising the minimum school-leaving age and referred also to its bearing on the wise use of leisure. Apart from Lord Taylor, speakers in the debate made little reference to the universities, but Lord James of Rusholme stressed the urgency of expansion and thought that the target of 170,000 students by the early 1970's was neither large enough nor likely to be reached without a new sense of urgency. He thought that the universities should see themselves as one end of a spectrum of higher education, distinguished from the others by the relative difficulty and originality of the ideas discussed and evaluated within their walls. He had fow misgivings about standards, but some about the possible loss of liberty. While he himself regarded the Ministry of Education as a friend and an enlightened counsellor, it was vital that whatever administrative changes were made the essential liberties of institutions of higher learning should be defined by those who value them, and respected by those who administer them. The liberties to think, to speak, to publish the truth as one sees it; to decide what are the standards to be maintained and the studies to be pursued; to follow the argument where it leads-these are the essentials of teaching and research at the highest level, and on their preservation depends the quality of higher education.

In replying on the debate for the Government, the Earl of Dundee made no comment on Lord Tayler's suggestion that the Ministry of Education should take over from the Treasury its responsibilities for university education, but pointed out that by $1966-67$ besides 150,000 students at universities there would be 137,000 students at teacher training colleges, colleges of advanced technology and other advanced technical colleges, or 10 per cent of the relevant age group, and a good deal higher in 1970.

\section{RESEARCH INTO STRATEGIC TRANSPORT PLANNING}

$I^{\mathrm{N}}$ replying for the Governmont in a debate on the needs of transport for research in the House of Commons on July 30, which was opened by Mr. W. T. Rodgers, who asked specifically about economic studies, the oncouragement given to postgraduate training, and research into strategic transport planning, the Parliamentary Secretary to the Ministry of Transport, Mr. T. G. D. Galbraith, said that the aim in the Ministry should be to keep a balance between action and rescarch. Sometimes only when dealing with a problem in practice could one see where the difficulties lay, what additional information would be helpful, and where more research was needed. In transport, research was best concentrated, therefore, so as to help the solution of actual problems of policy and planning. This was recognized in the Hall Report, which gave the general outlook for traffic in 1981, and began with a statement of the fundamental problems confronting the Ministry before discussing possible lines of research. In transport in cities, for example, the difficulty was to obtain a solution which gave the right balance between conflicting interests. To do so it was necessary to discover tho future pattern of personal travel, the strength of preferences for different patterns of travel, the futuro needs for the movemont of goods, the pattern of transport facilities to-day, and the costs of adding to them in various ways, etc. Even with all the facts from such a survey, techniques of handling this knowledge were required and over the whole range of transport there were in fact two stages: research to discover the facts, and research to enable the right lessons to bo drawn from them.

The Hall Report and the Beeching Report (see Nature, 198,$1233 ; 1963$ ) were two examples of research which had been proceeding to obtain the facts; on the urban side, the Buchanan Report would soon be available, with its wide implications for city life, and the Ministry and the London County Council had jointly commissioned the London Traffic Survey, which would give detailed informa. tion of future traffic needs to enable these to be related to changes in employment, rosidential patterns, etc. The 
survey was being undertaken jointly by British and American consultants working together. The Merseyside Survey should be ready this year and others would follow, while the City of Glasgow had requested a comprehensive survey to cover the Clyde Valley. Parallel with these special studies was a continuing programme of research to find out more about long-term trends in transport, examples of which were the large-scale sample survey of roadgoods transport and continuing series of surveys of the ownership and use of private cars recently undertaken.

Mr. Galbraith pointed out that many of the skills required were those of economists, and for this interpretation it was necessary to rely largely on outside sources such as the universities, where transport research was developing in two ways: the first was in the growth of traffic engineering from engineering proper into the wider questions of the economics of transport, pricing, and so on. Secondly, there was increasing interest in transport as a subject of its own with the overall field of economics. The Government was endeavouring to increase the demand for traffic engineers by emphasizing to local authorities the value of such engineers, and the Ministry had been strengthening its links with the universities, and a useful two-way traffic in ideas was developing. It was proposed to use the token sum specially voted for research to stimulate more research and where appropriate to commission specific studies which would help in making policy decisions. An example was the cost-bonefit study of investment in a railway electrification scheme just commissioned with British Railways, and the Road Research Laboratory had done a good deal of work on this technique in relation to roads.

\section{ROTHAMSTED EXPERIMENTAL STATION}

\section{REPORT FOR 1962}

$\mathrm{T}$ HE size of a modern research station and the range of its activities is such that to keep in touch with its activities by roading the annual report is a major undertaking. Yet to have compressed a report on the work of Rothamsted into little more than 300 pages is in itself a substantial achievement*

The place of Rothamsted in agricultural science is evident in the notes on personalities and events. Threo members of the staff were elected to fellowships of the Royal Society, and invitations to staff members to visit other countries were more than could be accepted without detriment to their work.

The name of Rothamsted is particularly associated with work on soils, and on the conditions that determine their fertility. A.s Mr. F. C. Bawden, the director, remarks, "There are many reasons for needing to increase crop yields, but no minor one is that when agriculture is inefficient, it is profligate in its use of land". A great part of the work reported is directed towards the more economical use of this basic agricultural resource. The Soil Survey of England and Wales is based at Rothamsted, and Rothamsted provides a base for the Common. wealth Bureau of Soils. Through these two organizations its influence extends both over Britain and to the world at large.

The high level of fertility characteristic of the agricultural soils of England has been brought about very largely as a result of the work on manures and fortilizers at Rothamsted. Progress has been such that in recent * Lawes Agricultural Trust. Rothamsted Experimental Station-Report
for 1962. Pp. 316. (Harpenden: Rothamsted Experimental Station, 1963.) years water has increasingly become the limiting factor in yields. Rainfall is barely adequate for unrestricted crop growth in eastern England, and oven where the annual total is sufficient, irregularities in distribution give rise to shortages over periods long enough to depress yiclds. Under Penman's leadership, the Physics Department has opened up a most productive field of work on water supply in the soil and the consumptive use of water by crops. A few years ago it might have boen argued that water, though the most important, was the least understood of the major plant nutrients. To-day, water ranks with the classic mineral elements in the fertility invostigations at Rothamsted.

It was at Rothamsted that R. A. Fisher, whose sad death is recorded in this report, carried out the studies that established new standards of precision in biological experimentation. The enterprise that started with one man on a temporary basis is now a large and world-famous department, making extensive use of computers, and providing advice and guidance as well as computation service both in Britain and to Commonwealth countries overseas.

A report is primarily a record of work done, and this report is worth all its three hundred pages. In his wise and critical discussion of "The Use and A.buse of Toxic Chemicals" the director contributes to the assessment of the impact of research on agriculture and society. If it is permissible, after so comprehensive a report, to ask for a little more, one might hope that the director will in future use the general report more extensively for this kind of evaluation.
J. B. HuTCHINSON

\section{RADIO RESEARCH 1962}

\footnotetext{
HEE report of the Radio Research Board*, under its new chairman, Dr. E. Eastwood, has recontly been published. It states that 1962 was an eventful year in the life of the Radio Research Station in so far as its work is now making use of rockets and satellites for exploring the Farth's atmosphere out to more than $1,000 \mathrm{~km}$, and obtaining a better understanding of the dependence of its physical characteristics on the Sun's radiation.

Two successful skylark rocket firings have been made at Woomera, carrying experiments devised at the Station in collaboration with the University of Sheffeld, and these are boing continued during the present year. By cooperation with the Canadian and American authorities,

* Department of Scientific and Industrial Research. Radio Research 1962: The Report of the Radio Research Board and the Report of the Director of Radio Research. Pp. iv $+26+4$ figs. +2 plates. (London: H.M.S. O., 1963.) 3s. net.
}

the ionosphere is now being explored from above as woll as from the older establishod ground observatories. In assisting other universities and organizations in the conduct of experiments in satellites which are relevant to the Station's research programme, the network of tracking stations under its control has accumulated extensive telemetry records on magnetic tapos. So far these records have been sent to the U.S. National Aeronautics and Space Administration for processing, but arrangements are now in hand for the first stage of the processing to be carried out at the Radio Research Station. Liaison with other workers in the United Kingdom is maintained through the British National Committee for Space Research under the auspices of the Royal Society.

In its programme of research on the ionosphere, considerable attention has been directed to exploring the 